\title{
TIPE KEPRIBADIAN, PENERIMAAN PERILAKU DISFUNGSIONAL DAN KEPUTUSAN AUDIT
}

\author{
Ika Kristianti \\ Universitas Kristen Satya Wacana, Indonesia \\ Email: ika.kristianti@staff.uksw.edu
}

\begin{abstract}
Abstrak: Tipe Kepribadian, Penerimaan Perilaku Disfungsional dan Keputusan Audit. Penelitian ini bertujuan untuk mendeskripsikan tipe kepribadian, penerimaan perilaku disfungsional dan pengambilan keputusan audit yang diambil oleh auditor. Penelitian ini dilakukan di Propinsi Jawa Tengah dengan 63 responden dari auditor di Kantor Akuntan Publik kota Semarang dan Solo. Teknik pengambilan sampel menggunakan purposive sampling. Hasil penelitian menunjukkan bahwa dalam menetapkan keputusan audit berisiko, jumlah auditor dengan tipe kepribadian B lebih banyak jika dibandingkan auditor dengan tipe kepribadian A. Begitu pula dalam menetapkan keputusan audit tidak berisiko, tipe kepribadian $B$ lebih banyak dibandingkan dengan auditor yang memiliki tipe kepribadian A. Hasil pengolahan data penerimaan perilaku disfungsional memberikan hasil bahwa auditor yang menerima perilaku disfungsional membuat keputusan audit yang lebih berisiko dibandingkan dengan auditor yang menolak perilaku disfungsional
\end{abstract}

Kata Kunci: Keputusan audit, tipe kepribadian dan penerimaan perilaku disfungsional.

\begin{abstract}
Type of Personality, Acceptance of Dysfunctional Behavior and Audit Judgment. This study aimed to describe the type of personality, acceptance of dysfunctional behavior toward audit judgment. This research was conducted in the province of Central Java, with 63respondents from the auditor on Public Accounting Firm city of Semarang and Solo. The sampling technique used purposive sampling. The results showed that the decision establishes audit risk, the number of auditors with the personality type $B$ is more than that type $A$. Meanwhile, in setting the audit decision is not at risk, personality type $B$ more than that type $A$. The results of data processing reception dysfunctional behaviors provide results that auditors receive audit dysfunctional behaviors make decisions more risk than the auditor who refused dysfunctional behavior.
\end{abstract}

Keywords: Audit judgment, personality type and acceptance of dysfunctional behavior.

\section{PENDAHULUAN}

Faktor teknis yang berpengaruh terhadap keputusan audit antara lain pengetahuan, pengalaman, perilaku auditor, tekanan dari atasan maupun pihak eksternal, kognisi pekerjaan serta kompleksitas tugas saat melakukan pemeriksaan (Irwanti, 2011; Davis et.al., 2006; Leung dan Trotman, 2005; Setiawan dan Iswari, 2016). Selain secara teknis, faktor non teknis juga memengaruhi keputusan audit. Chung dan Monroe (2001), Davis (2006) memberi bukti empiris bahwa gender, tekanan social akan berpengaruh terhadap pengambilan keputusan oleh auditor.

Riset ini memfokuskan pada tipe kepribadian dan penerimaan atas perilaku disfungsional yang dikaitkan dengan 
keputusan audit yang berisiko. Pria dan wanita memiliki kepribadian yang berbeda, begitu pula dengan perbedaan reaksi emosional dan kemampuan membaca orang lain serta proses pengolahan informasi yang berbeda (Robbins, 2006; Monroe, 2001). Begitu pula penelitian yang dilakukan oleh Robbins dan Judge (2013) yang memberikan hasil bahwa tipe kepribadian berpengaruh terhadap pengambilan keputusan. Beberapa penelitian lain menunjukkan bahwa karakteristik individu dari auditor merupakan penentu yang signifikan dari kinerjanya, karakteristik inilah yang dianggap sebagai elemen yang penting daripada elemen lain (Solomon dan Trotman, 2003; Brocheler et.al., 2004). Sedangkan penelitian Robbins dan Judge (2013) memberikan hasil bahwa kepribadian tidak berpengaruh terhadap pengambilan keputusan oleh individu.

Menurut Friedman dan Rosenman (1974) yang memperkenalkan pembagian tipe kepribadian menjadi Tipe A dan Tipe B, seseorang yang berkepribadian tipe kepribadian A adalah seseorang yang cenderung ambisius, kompetitif, berorientasi pada prestasi, dan mempunyai kecenderungan tidak sabar. Seseorang dengan tipe kepribadian B akan cenderung lebih santai, tidak suka berkompetitif, dan mempunyai tingkat stress yang lebih rendah. Hasil penelitian Yustino dan Iswari (2016) menunjukkan bahwa dari perspektif tipe kepribadian umumnya lebih berorientasi pada prestasi dan keinginan untuk menang, sehingga lebih mungkin untuk menghasilkan penilaian audit yang lebih tinggi. Sejalan dengan hasil penelitian tersebut, Utami dan Nahartyo (2013) memprediksikan bahwa tipe A akan meningkatkan hubungan positif antara konflik peran, ambiguitas peran, dan tumpang tindih peran terhadap burnout di antara auditor.

Ada kalanya opini audit kurang mendapatkan respon yang positif dikarenakan adanya kemungkinan terjadinya penyimpangan perilaku oleh seorang auditor dalam proses audit (Donellyetal., 2003). AICPA melakukan pemeriksaan terhadap masalah kualitas audit, dan mengumpulkan informasi dari survey auditor internal dan auditor eksternal yang menunjukkan hasil bahwa perilaku penyimpangan audit tetap ada dan akan terus menjadi kekhawatiran untuk profesi auditor (Donelly et.al.,, 2011). Penelitian terdahulu, lebih banyak mengungkapkan penyimpangan perilaku terhadap lingkungan eksternal, seperti penandatanganan terlalu cepat (premature signing off) (Otley\& Pierce, 1995), pengumpulan bukti yang tidak cukup (Donelly, et.al.,, 2011).

Penerimaan atas perilaku menyimpang akan mempengaruhi bagaimana proses audit akan dilakukan. Penyimpangan perilaku atas pengambilan keputusan auditor, akan mempengaruhi proses audit lainnya. Pertimbangan audit mengacu pada penilaian subjektif yang dibuat sebagai tindakan awal dalam proses audit. Pertimbangan auditor penting dalam proses audit karena mencakup kompetensi auditor, efektivitas arsitektur sistem informasi bagi auditor, dan signifikansi (materialitas) dari unsur laporan keuangan (Prachsriphum et.al., 2011).

Penelitian ini mendeskripsi tipe kepribadian A atau B serta penerimaan perilaku yang menyimpang auditor serta pengambilan keputusan oleh auditor di Jawa Tengah. Pengambilan keputusan audit oleh 
auditor akan berbeda-beda sesuai dengan tipe kepribadian yang dimiliki oleh auditor. Preferensi pengambilan risiko atas perilaku menyimpang akan berbeda pula jika auditor mempunyai tipe kepribadian yang berbeda.

Hasil penelitian ini diharapkan dapat berkontribusi pada lembaga profesi akuntan public tentang dinamika yang terjadi di dalam Kantor Akuntan Publik. Secara teoretis, hasil penelitian ini menambah pengetahuan di bidang akuntansi keperilakuan dan auditing untuk menjadi acuan untuk penelitian selanjutnya.

Dalam melaksanakan audit, auditor mengacu pada standar yang telah ditetapkan dalam standar auditing. Salah satu standar yang harus dipenuhi oleh auditor dalam pekerjaan audit adalah perencanaan audit. Di dalam perencanaan audit dikatakan bahwa auditor antara lain harus mempertimbangkan berbagai risiko audit dan tingkat materialitas awal untuk tujuan audit.

Dalam pelaksanaan prosedur audit yang mendetail, auditor membuat berbagai pengambilan keputusan yang akan mempengaruhi dokumentasi bukti dan keputusan pendapat auditor (DeZoort,2006). Pemahaman atas bisnis klien, penetapan kesinambungan usaha, dan indikasi atas potensi salah saji adalah salah satu dari prosedur awal dalam sebuah proses audit (Arens et.al., 2005). Kenyataan ini membuat auditor harus mengenali risiko dan tingkat materialitas mengenai saldo akun yang telah ditetapkan pada saat perencanaan audit. Pada tahap kesimpulan audit, untuk review akhir dalam menilai kewajaran penyajian laporan keuangan diperlukan pula pengambilan keputusan auditor dalam tahap akhir proses audit (Boynton dan Kell, 2001). Auditor perlu melakukan berbagai tugas untuk membentuk opini atas atestasi. Untuk melakukannya, banyak faktor pribadi auditor (misal keterampilan dan kepribadian) yang mempengaruhi hasil akhir dari pengambilan keputusan (Nelson dan Tan, 2005).

Pengambilan keputusan oleh auditor dianggap sebagai unsur yang paling penting dari seluruh proses audit dan akan langsung mempengaruhi kualitas audit (Wedemeyer 2010). Kualitas penilaian auditor menjadi penting karena tidak hanya mempengaruhi reputasi professional auditor, tetapi juga bisa berdampak pada pemangku kepentingan lainnya (Mala dan Chand, 2015). Penilaian professional auditor meliputi: (1) Penilaian risiko salah saji material laporan keuangan; (2) Identifikasi, kinerja dan penilaian prosedur audit untuk mengatasi resiko; serta (3) Evaluasi bukti audit untuk menentukan kualitas dan makna bukti (Wedemeyer, 2010). Hasil penilaian yang dibuat oleh auditor cukup bervariasi, meskipun auditor telah menggunakan fakta dan bukti yang sama (Martinov - Bennie dan Pflugrath, 2009; Wedemeyer, 2010). Ini menunjukkan bahwa penilaian auditor mungkin dipengaruhi oleh banyak factor.

Penelitian Sanusi dan Iskdanar (2006) memberikan hasil bahwa ada hubungan positif antara variable insentif kinerja dan penilaian audit. Penelitian lain juga menunjukkan dukungan terhadap hubungan antara insentif keuangan dan penilaian auditor (Arifuddin, 2014; Bonner dan Taburi 2002; Lee, 2012). Temuan lain berkaitan dengan pengambilan keputusan auditor menemukan bahwa data ringkasan manajemen ataupun kesimpulan atas proses 
audit tahun lalu berpengaruh terhadap pengambilan keputusan (McDaniel dan Kinney, 1995; Kennedy, 1995).

Keputusan yang diambil seseorang juga dipengaruhi oleh faktor psikologis seperti kepribadian (Miller, 2009). Penelitian Khan (2011) memberikan hasil bahwa perasaan burnout tidak dapat dipisahkan dari tipe kepribadian seseorang. Faktor yang dipertimbangkan dalam pengambilan keputusan seseorang adalah ideologi dan kekuasaan, serta emosi dan objekitivitas. Bagi sebagian orang, dalam mengambil keputusan dipengaruhi oleh suatu filosofi atau prinsip tertentu. Sedangkan bagi sebagian yang lain, pengambilan keputusan didasarkan pada kekuasaan yang dimiliki.

Berdasarkan teori kognitif, karakter personal mempunyai hubungan langsung pada pengambilan keputusan individu dan kepribadian (Chakraborty, et.al., 2008; Dutta dan Thornhill, 2008). Dalam hal ini, pengambilan pertimbangan secara tidak bias adalah inti dari peningkatan karakteristik dalam pertimbangan auditor dan dapat mengurangi distorsi pertimbangan audit yang akan mempengaruhi rencana pengambilan keputusan audit dan kinerja audit (Lim-u-sanno, 2009)

Dalam pengambilan keputusan yang akan diambil oleh auditor menyangkut pengambilan keputusan audit, akan dipengaruhi oleh kepribadian dari masingmasing auditor. Menurut Frieldman dan Rosenman (1974) tipe kepribadian ada dua jenis, yaitu tipe kepribadian A dan tipe kepribadian B. Mereka menyimpulkan bahwa orang yang mempunyai tipe kepribadian A sangat kompetitif dan berorientasi pada pencapaian, merasa waktu selalu mendesak, sulit untuk bersantai dan menjadi tidak sabar dan marah jika berhadapan dengan keterlambatan atau dengan orang yang dipandang tidak kompeten. Sedangkan orang dengan tipe kepribadian B lebih mampu bersantai tanpa merasa bersalah dan bekerja tanpa melihat nafsu, tidak harus tergesa-gesa yang menyebabkan ketidaksabaran dan tidak mudah marah.

Penelitian mengenai tipe kepribadian dan pengambilan keputusan memberikan hasil bahwa kepribadian seseorang akan mempengaruhi pengambilan keputusan (Robbins dan Judge, 2013). Sejumlah penelitian perilaku menyelidiki apakah kepribadian auditor dan karakteristik individu mempengaruhi perilaku auditor. Misalnya, penelitian oleh Iswari dan Kusuma (2013) menunjukkan hasil bahwa tipe kepribadian memiliki pengaruh pada konflik professional dalam sebuah organisasi. Utami dan Nahartyo (2013) menemukan bukti bahwa kepribadian tipe A mengintensifkan konflik kepentingan dan tumpang tindih aturan terhadap kejenuhan auditor. Ini mengindikasikan bahwa auditor dengan tipe kepribadian A, akan lebih rentan terhadap stress yang berhubungan dengan pekerjaan. Sementara itu, Ismail (2015) tidak menemukan bukti bahwa kepribadian auditor berpengaruh secara signifikan terhadap keputusan audit.

Rayburn dan Rayburn menemukan bukti bahwa tipe kepribadian $\mathrm{A}$ lebih berorientasi etis dibandingkan dengan tipe kepribadian B. Hasil ini juga didukung oleh Chadegani et.al., (2015) bahwa ada hubungan signifikan antara kepribadian auditor dan niat auditor dalam melaporkan 
kesalahan. Auditor yang berkepribadian tipe $A$ akan lebih berniat melaporkan kesalahan dibandingkan dengan kepribadian tipe B.

Kreitner (2005) memberikan penjelasan mengenai pola perilaku tipe A yang merupakan suatu kompleks tindakan emosi yang dapat diamati dalam setiap orang yang terlibat secara agresif untuk mencapai hal yang lebih baik, dan lebih dalam waktu singkat. Individu dengan jenis kepribadian tipe A adalah manusia yang tak hentihentinya ingin mencapai sesuatu yang lebih tinggi (tinggi dan banyak). Sedangkan lawan dari jenis kepribadian tipe $A$ adalah jenis kepribadian B. Individu dengan jenis kepribadian tipe $B$ jarang berperilaku untuk saling bersaing atau bersikap agresif dalam keadaan-keadaan di mana perilaku berkompetisi dianggap tidak wajar dan tidak penting. Dengan kepribadian dasar tipe $A$ yang cenderung untuk berani mengambil risiko, maka pengambilan keputusan audit yang dihasilkan akan lebih berisiko jika dibandingkan dengan auditor dengan tipe kepribadian B.

Penelitian yang berkaitan dengan penerimaan perilaku disfungsional telah menunjukkan korelasi yang kuat antara locus of control dan kemauan individu untuk kemampuannya memanipulasi dan menipu (Gable dan Dangello 1994; Comer 1985; Solar dan Bruehl 1971). Perilaku yang paling mungkin untuk mewujudkan situasi keamanan dan kenyamanan karyawan adalah dengan cara memanipulasi keadaan. Dalam berbagai situasi untuk mempertahankan pekerjaan, perilaku individu untuk memilih atau melakukan sesuatu ditentukan oleh opini mereka. Pilihan seorang auditor untuk menerima perilaku audit disfungsional dapat dipengaruhi oleh opini individu auditor. Kemampuan auditor untuk melakukan program audit sesuai dengan prosedur audit merupakan faktor yang sangat penting. Auditor yang mampu melaksanakan audit sesuai dengan program audit akan memilih untuk bertindak fungsional, sedangkan auditor yang tidak mampu melaksanakan audit sesuai dengan program audit akan termotivasi untuk menerima perilaku audit disfungsional (Gable dan Dangello, 1994).

Dalam melaksanakan tugasnya, auditor harus mengikuti standar audit yang terdiri dari standar umum, standar pekerjaan lapangan dan standar pelaporan serta kode etik auditor. Dalam kenyataan, auditor banyak melakukan penyimpangan terhadap standar audit dan kode etik. Perilaku ini diperkirakan sebagai akibat dari adanya tipe kepribadian auditor di samping adanya kemungkinan lainnya. Dampak negatif dari perilaku ini adalah terpengaruhnya kualitas audit secara negatif dari segi keakuratan dan reliabilitas. Penyimpangan yang dilakukan auditor dalam audit dapat dikategorikan sebagai sebuah perilaku disfungsional dalam audit (Donelly et.al., 2003).

Penerimaan perilaku disfungsional merupakan suatu bentuk reaksi terhadap lingkungan atau semisal sistem pengendalian (Otley dan Pierce, 1995; Lightner et.al., 1983; Alderman dan Deitrick, 1982 dalam Donelly et.al., 2003). Sistem pengendalian yang berlebihan akan menyebabkan terjadinya konflik dan mengarah pada perilaku disfungsional. Donellyet.al., menyatakan bahwa sikap auditor yang menerima perilaku disfungsional merupakan indikator perilaku disfungsional aktual. 
Berbagai situasi dan kondisi yang dihadapi oleh auditor sering kali akan membuat bimbang auditor dalam menentukan sikap. Semakin auditor merasa tertekan dengan pekerjaan yang dilakukan, akan semakin mudah auditor tersebut melakukan perilaku disfungsional. Penelitian oleh DeZoort dan Lord (1994) mengindikasikan bahwa adanya pengaruh dari tekanan atasan pada judgment yang diambil oleh auditor pemula. Jika auditor melakukan perilaku disfungsional maka dalam pengambilan keputusan audit akan lebih tidak etis, jika dibandingkan dengan auditor yang tidak menerima perilaku disfungsional

\section{METODE}

Penelitian ini merupakan studi deskriptif yang menyajikan data dari auditor yang bekerja di Kantor Auditor Publik (KAP) di Jawa Tengah. Pengambilan sampel pada penelitian ini dengan menggunakan teknik purposive sampling, yang didasarkan pada criteria: (1) auditor yang bekerja pada Kantor Akuntan Publik di kota Semarang dan Solo; (2) minimal level responden auditor adalah senior; (3) lama bekerja pada Kantor Akuntan Publik tersebut minimal 2 tahun; (4) auditor yang bekerja pada KAP Jawa Tengah yang terdaftar pada Directory Kantor Akuntan Publik yang dikeluarkan IAI pada tahun 2011. Data yang disajikan meliputi tabulasi silang data demografi responden dengan variabel tipe kepribadian, keputusan audit dan penerimaan perilaku disfungsional auditor.

Dalam penelitian ini meneliti tentang keputusan audit, tipe kepribadian dan penerimaan perilaku disfungsional. Variabel dependen yang digunakan adalah keputusan audit, sedangkan variabel independen adalah tipe kepribadian dan penerimaan perilaku disfungsional.

Berikut ini akan dijelaskan mengenai indicator setiap variabel yang terkait dengan penelitian. Keputusan audit merupakan kebijakan auditor dalam menentukan pendapat mengenai hasil audit yang mengacu pada penentuan suatu gagasan, pendapat atau perkiraan tentang suatu objek, status, atau peristiwa lainnya. Variabel ini diukur dengan menggunakan instrumen yang mengacu pada penelitian Jamilah (2007). Instrumen ini diukur dengan dua kasus sederhana dengan tiga item pertanyaan untuk setiap kasus. Kasus tersebut meliputi kasus tingkat materialitas dan rekayasa transaksi atas entitas yang diperiksa. Berdasarkan masing-masing kasus tersebut, keputusan yang diminta adalah mengikuti atau tidak permintaan entitas yang diperiksa. Skala pengukuran yang digunakan adalah skala likertlima poin, yaitu $1=$ rendah sekali, $2=$ rendah, $3=$ netral, $4=$ tinggi, dan $5=$ sangat tinggi .

Tipe kepribadian merupakan organisasi dinamis dalam system psikologis individu yang menentukan caranya untuk menyesuaikan diri secara unik terhadap lingkungannya (Robbins, 2007). Variabel ini diukur dengan memberikan pernyataan sebanyak tiga puluh dua item. Pernyataan terbagi menjadi dua bagian yang bertolak belakang, yang akan mengindikasikan tipe kepribadian dari masing-masing auditor. Bagian pertama mempunyai kecenderungan untuk tipe kepribadian $A$, sedangkan bagian berikutnya memiliki kecenderungan jawaban tipe kepribadian B. Skala pengukuran yang digunakan adalah skala Likert lima point, 
Tabel 1. Data Demografi Responden

\begin{tabular}{lcc}
\hline \multicolumn{1}{c}{ Keterangan } & Jumlah & Persentase \\
\hline Jenis Kelamin & & \\
- Wanita & 19 & $30.16 \%$ \\
- Pria & 44 & $69.84 \%$ \\
Jumlah & 63 & $100 \%$ \\
\hline Jabatan & & \\
- Senior Auditor & 50 & $79.37 \%$ \\
- Supervisor & 13 & $20.63 \%$ \\
Jumlah & 63 & $100 \%$ \\
\hline
\end{tabular}

yaitu 1 = rendah sekali, 2 = rendah, 3 = netral, $4=$ tinggi, dan $5=$ sangat tinggi.

Penerimaan perilaku disfungsional adalah pandangan auditor tentang perilaku disfungsional audit. Variabel penerimaan perilaku disfungsional dalam kuesioner terdiri dari tiga tipe perilaku, yaitu premature sign off, perubahan dalam prosedur audit, dan percepatan pelaporan audit. Variabel ini diukur dengan menggunakan dua belas indicator pertanyaan yang dikembangkan oleh Donelly et.al. (2003). Setiap jawaban diproyeksikan dengan skala likertlima point, yaitu 1 = rendah sekali, 2 = rendah, 3 = netral, $4=$ tinggi, dan 5 = sangat tinggi.

\section{HASIL DAN PEMBAHASAN}

Dari total 63 responden, $44(69,84 \%)$, adalah auditor pria dan $19(30,16 \%)$ lainnya adalah auditor wanita. Jabatan responden mayoritas adalah senior auditor yang memiliki lama bekerja lebih dari 2 tahun di bidang yang sama. Tabel 1 menyajikan data demografi auditor yang diperoleh.

Instrumen validitas diuji dengan menggunakan korelasi Pearson produk moment. Koefisien akan dianggap valid apabila nilai korelasi Pearson lebih besar dari 0,3 (Arifudin, 2014). Hasil dari pengujian Pearson, menghasilkan 9 instrumen tipe kepribadian A valid, dan 11 instrumen kepribadian B dinyatakan valid. Hasil ini disajikan pada tabel 2.

Instrumen penelitian umumnya dianggap reliabel jika Cronbach Alpha lebih besar dari 0,6 (Sugiyono, 2010). Dalam uji reliabilitas penelitian ini, menunjukkan bahwa instrumen untuk tipe kepribadian A sebesar 0,762 (lebih besar dari 0,6) dan untuk instrument tipe kepribadian B sebesar 0,764 (lebih besar dari 0,6). Sehingga bisa diambil kesimpulan bahwa instrument tipe kepribadian reliabel dalam penelitian ini.

\section{Hubungan antara Tipe Kepribadian dengan Keputusan Audit}

Berdasarkan data yang telah diolah berkaitan dengan variabel tipe kepribadian dan keputusan audit, maka dapat diperoleh Persentase skor masing-masing indikator yang disajikan dalam tabel 2 .

Tabel 2. Persentase Skor Tipe Kepribadian dan Keputusan Audit

\begin{tabular}{lc|c}
\hline & \multicolumn{2}{c}{ Keputusan Audit } \\
\cline { 2 - 3 } Tipe Kepribadian & Berisiko & TidakBeresiko \\
\hline Tipe A & $32,3 \%$ & $11,86 \%$ \\
Tipe B & $38,98 \%$ & $16,95 \%$ \\
Total & $71,28 \%$ & $28,81 \%$ \\
\hline
\end{tabular}


Dari hasil pengumpulan dan pengolahan data, diketahui bahwa $71,28 \%$ auditor cenderung mengambil risiko dalam sebuah pengambilan keputusan. Auditor dengan tipe kepribadian $A$ dan $B$, masing-masing juga mempunyai kecenderungan yang sama dalam pengambilan keputusan berisiko. Berdasarkan data tersebut dapat terlihat bahwa kecenderungan auditor yang memiliki tipe kepribadian B mengambil keputusan yang lebih berisiko dibandingkan dengan keputusan yang diambil oleh tipe kepribadian A. Kemungkinan yang bisa terjadi adalah bahwa secara independen variabel tipe kepribadian tidak memengaruhi secara langsung pengambilan keputusan audit. Dalam penelitian Mala dan Chand (2015) menyatakan bahwa factor yang memengaruhi pengambilan keputusan audit ada 3 bagian besar, yaitu variabel pribadi (pengetahuan, keahlian, pengolahan informasi, dan keyakinan); variabel tugas (kompleksitas tugas dan resiko); serta variabel lingkungan (tekanan waktu, pengendalian internal, dan akuntabilitas). Tipe kepribadian dapat diklasifikasikan sebagai salah satu variabel pribadi, yang hanya menjadi satu dari banyak factor yang memengaruhi pengambilan keputusan audit.

\section{Hubungan Perilaku Disfungsional dengan Keputusan Audit}

Dari hasil pengolahan data, didapatkan persentase skor penerimaan dan penolakan perilaku disfungsional terhadap keputusan audit yang diambil oleh auditor. Hasil tersebut tercantum dalam tabel 3.

Berdasarkan output deskriptif diperoleh auditor yang menerima perilaku disfungsional dan mengambil keputusan berisiko sebanyak 39\%, sedangkan auditor yang menerima perilaku disfungsional namun tidak mengambil keputusan berisiko sebanyak 16,95\%. Auditor yang menolak perilaku disfungsional dan mengambil keputusan berisiko sebanyak $11,85 \%$; serta auditor yang menolak perilaku disfungsional dan mengambil keputusan audit tidak berisiko sebanyak $32,20 \%$.

Tabel 3. Persentase Skor Penerimaan Perilaku Disfungsional dan Keputusan Audit

\begin{tabular}{lc|c}
\hline & \multicolumn{2}{c}{ Keputusan Audit } \\
\cline { 2 - 3 } & Berisiko & $\begin{array}{c}\text { Tidak } \\
\text { Beresiko }\end{array}$ \\
\hline $\begin{array}{l}\text { Penerimaan } \\
\text { Perilaku } \\
\text { Disfungsional }\end{array}$ & $39 \%$ & $16,95 \%$ \\
$\begin{array}{l}\text { Penolakan Perilaku } \\
\text { Disfungsional } \\
\text { Total }\end{array}$ & $11,85 \%$ & $32,20 \%$ \\
\hline
\end{tabular}

Auditor yang menerima perilaku disfungsional mayoritas memiliki tipe kepribadian A (sebanyak 23 auditor). Keputusan yang dibuat oleh auditor yang menerima perilaku disfungsional memiliki kecenderungan untuk mengambil keputusan secara lebih berisiko dibanding dengan auditor dengan yang menolak perilaku disfungsional. Sedangkan untuk auditor yang menerima perilaku disfungsional dan mempunyai tipe kepribadian B sebanyak 10 orang.

Auditor dengan tipe kepribadian A maupun $B$ cenderung mempertimbangkan sikap profesionalnya saat melakukan proses audit. Kemungkinan yang terjadi adalah auditor mengedepankan sikap profesionalitas dalam pekerjaannya. Karena profesi auditor dibatasi oleh kode etik dan standar professional. Hasil penelitian ini 
mendukung penelitian yang dilakukan oleh Ismail (2015) yang menyebutkan bahwa tipe kepribadian tidak memberikan pengaruh terhadap keputusan audit

Hasil penelitian ini mengindikasikan bahwa jumlah auditor yang menerima perilaku disfungsional maka pengambilan keputusan yang berkaitan dengan proses audit akan semakin berisiko, jika dibandingkan dengan jumlah auditor yang menolak perilaku disfungsional. Teori kognisi memberikan pendapat bahwa seseorang akan mengambil keputusan sesuai dengan opini yang mereka anut. Auditor yang mampu untuk mempertahankan prosedur audit dengan benar dan mampu untuk mengerjakan setiap proses audit dengan benar, maka dia akan cenderung untuk menolak perilaku disfungsional. Auditor yang menolak perilaku disfungsional akan menghasilkan audit judgment yang lebih etis jika dibandingkan dengan auditor yang menerima perilaku disfungsional.

Auditor mengerjakan setiap proses audit secara terprogram dan sesuai dengan prosedur, serta melakukan penolakan terhadap perilaku yang menyimpang. Ini dimungkinkan karena auditor terikat dengan etika profesi dalam setiap penugasan audit (Ismail, 2015). Dengan profesionalisme yang baik, seseorang akan mampu melaksanakan tugasnya meskipun imbalan ekstrinsiknya berkurang, selain itu dengan profesionalisme seorang akan mampu untuk membuat keputusan tanpa tekanan pihak lain, akan selalu bertukar pikiran dengan rekan sesama profesi, dan selalu beranggapan bahwa yang paling berwenang untuk menilai pekerjaannya adalah rekan sesama profesi sehingga dengan profesionalisme yang tinggi kemampuan dalam mempertimbangkan tingkat materialitas suatu laporan keuangan akan semakin baik pula (Yendrawati, 2008 ).

\section{SIMPULAN}

Hasil penelitian menunjukkan bahwa dalam menetapkan keputusan audit berisiko, jumlah auditor dengan tipe kepribadian B lebih banyak jika dibandingkan auditor dengan tipe kepribadian A. Sementara itu, dalam menetapkan keputusan audit tidak berisiko, tipe kepribadian B lebih banyak dibandingkan dengan auditor yang memiliki tipe kepribadian A. Hasil pengolahan data penerimaan perilaku disfungsional memberikan hasil bahwa auditor yang menerima perilaku disfungsional membuat keputusan audit yang lebih berisiko dibandingkan dengan auditor yang menolak perilaku disfungsional

Keterbatasan dalam penelitian ini adalah dalam pengambilan sampel, yaitu terbatas pada KAP yang berada dalam wilayah Jawa Tengah (khususnya Kota Semarang dan Kota Solo), tidak mencakup keseluruhan KAP. Indikator penelitian hanya terbatas pada pengambilan keputusan audit, tipe kepribadian dan penerimaan perilaku disfungsional. Demikian pula pengisian kuesioner tidak diawasi secara langsung oleh peneliti, sehingga ada kekhawatiran perbedaan penafsiran pemahaman oleh responden.

Berdasarkan hasil penelitian dan keterbatasan, dapat dikemukakan beberapa pertimbangan untuk penelitian lanjutan. Populasi dan sampel bisa diperluas, tidak hanya di Kantor Akuntan Publik di Jawa Tengah. Penelitian lebih lanjut disarankan untuk menggunakan variabel lain yang 
berpengaruh terhadap pengambilan keputusan audit. Penelitian juga dapat menggunakan dengan metoda lain misalnya metoda eksperimen yang menguji hubungan kausalitas suatu variabel dependen dengan independen. Pengembangan juga dapat diteliti keputusan audit dalam kondisi keputusan kelompok.

\section{DAFTAR PUSTAKA}

Chakraborty, I., Hu, P. J. \& Cui, D. (2008). Examining the Effects of Cognitive Style in Individuals' Technology Use Decision Making, Decision Support Systems, 45, 228-241.

DeZoort, T, Harrison, P., \& Taylor, M. (2006). Accountability \& Auditors' Materiality Judgements: The Effects of Differential Pressure Strength on Conservatism, Variability, dan Effect. Accounting, Organization and Society, 31(1), 373390.

Dutta, D. K. \& Thornhill, S. (2008). The Evaluation of Growth Inventions: Toward a Cognition-Based Model, Journal of Business Venturing, 23, 307-332.

Friedman \& Rosenman, (1974). Type A Behavior dan Your Heart. New York: Afred A. Knop.

IAI-Kompartemen Akuntan Publik, (2001). Standar Profesional Akuntan Publik. Jakarta: PT Salemba Empat.

Ismail, F. (2015). Pengaruh Tipe Kepribadian, Pengalaman dan Penerimaan Perilaku Disfungsional terhadap Audit Judgment. Jurnal Bisnis dan Manajemen, 5(2), 263278.

Iswari, T.I \& Kusuma, I.W. (2013). The Effect of Organizational-Professional Conflict towards Professional Judgment by Public Accountant Using Personality Type, Gender, dan Locus of Control as Moderating Variables. Review of
Integrative Business \& Economics Research, 2(2), 434-448.

Jamilah, S., Fanani, Z., \& Chandrarin, G. (2007). Pengaruh Gender, Tekanan Ketaatan, dan Kompleksitas Tugas Terhadap Audit Judgment. Jurnal SNA $X$ Makassar.

Kennedy, J. (1993). Debiasing Audit Judgment with Accountability: A Framework dan Experimental Results. Journal of Accounting Research, 31(2), 231-245.

Kreitner \& Kinicki. (2005). Perilaku Organisasi, buku 1. Jakarta: PT Salemba Empat.

Lim-u-sanno, Kulwadee. (2009). Audit Risk Judgment dan Performance of Thai Auditors: An Empirical Investigation of Their Antecedents dan Consequences. Journal of Academy of Business dan Economics, 9(3).

Mala, R \& Chand, P. (2015). Judgment dan Decision-Making Research in Auditing dan Accounting: Future Research Implications of Person, Task, and Environment Perspective. Accounting Perspective. 14(1). 1-50.

Miller, J.D., (2009). Teori-teori Pengambilan Keputusan. Diakses dari http://hendriansdiamond.blogspot.com/ 2012/01/choice-menurut-terry-1989faktor-faktor.html pada tanggal 23 Februari 2012.

Mohd-Sanusi, Z. \& Mohd-Iskdanar T. (2006). Audit Judgment Performance: Assessing The Effect of Performance Incentives, Effort and Task Complexity. Managerial Auditing Journal. 22 (1). 34 - 52.

Prachsriphum, Suttinee, Chuchuea, \& Sunisa., (2011). Audit judgment competency dan audit reporting quality: an empirical research of tax-auditors in Thailand. Journal of Academy of Business dan Economics. 
Rayburn, J.M. \& Rayburn, L.G. (1996). Relationship Between Machiavellianism and Type A Personality and Ethical Orientation. Journal of Business Ethics. 15(11), 1209-1219.

Robbins, SP \& Judge, TA. (2013). Organizational Behavior (15 $5^{\text {th }}$ Edition). Pearson Education Limited.

Sugiyono. (2010). Metode penelitian bisnis (pendekatan kuantitatif, kualitatif, dan $R \& D$. Bandung: CV Alfabeta.

Utami, I \& Nahartyo, E. (2013). The effect of Type A Personality on Auditor Burnout: Evidence from Indonesia. Accounting \& Taxation. 5(2). 89-102.
Wedemeyer, (2010). A Discussion Of Auditor Judgment as The Critical Component in Audit Quality - A practitioner's Perspective. International Journal of Disclosure dan Governance 7, 320-333.

Yendrawati, R. (2008). Analisis Hubungan Antara Profesionalisme Auditor dengan Pertimbangan Tingkat Materialitas Dalam Proses Pengauditan Laporan Keuangan. Jurnal Penelitian dan Pengabdian, 6(1), 193.

Yustino, Wimpie \& Iswari, T.I. (2016). The Effects of Job Cognition and Personality Type On Auditor Judgment. Jurnal Siasat Bisnis. 20(1). 14-23. 